Jacek Witkoś

Adam Mickiewicz

University in Poznań*

Dominika Dziubała-Szrejbrowska

Adam Mickiewicz University in Poznań ${ }^{* *}$

\title{
SOME ASPECTS OF AGREEMENT WITH NUMERAL PHRASES IN POLISH***
}

\section{INTRODUCTION}

Patterns of agreement between a quantified subject and a verbal or adjectival predicate/ participle in Polish seem to pose a challenge to standard theories of Agree (cf. Chomsky $2000,2001,2008)$ as we observe a full subject-verb agreement, i.e., in person, number and gender, with subjects quantified by lower numerals, i.e., $<5$, e.g., (1a), whereas phrases with higher numerals, i.e., $\geq 5$, and numeral quantifiers exceptionally force default agreement, i.e., $3_{\mathrm{SG} . \mathrm{NEUT}}$, e.g., $(1 \mathrm{~b}){ }^{1}$
(1) a) $\operatorname{Trzy}$
kobiety
weszty
do budynku.
three ${ }_{N O M}$ 'Three wome
women $_{\text {NOM.FEM.PL }}$
entered $_{F E M . P L}$ to
to building
'Three women entered the building.'

\footnotetext{
* wjacek@wa.amu.edu.pl

** dziubala@wa.amu.edu.pl Polish Science Center.
(i) Dwóch/pięciu mężczyzn wyszło z budynku.
two/five IIR $_{\text {GEN.VIR.PL }}$ left $_{3 S G . N E U T}$ from building

'Two men left the building.'
}

*** Extensive parts of this material were presented at FDSL 10.5 in 2014 (4-6 December, Brno), The Agreement Across Borders Conference in 2015 (15-16 June, Zadar) and Slavic Linguistics Society in 2015 (4-5 September, Heidelberg), and appeared in Witkoś and Dziubała-Szrejbrowska (2016). This contribution is partially funded by grant no. 2012/07/B/HS2/02308 issued by the

1 Virile (masculine personal) lower numerals also trigger default agreement, i.e., $3_{\text {SG.NEUT, }}$ in Polish, e.g.

Yet, due to the syncretism between genitive and accusative in virile plural the case optionality in agreement with predicative adjectives and participles is not detectable, e.g.
(ii) Pięciu mężczyzn zostało wybranych do rady wydziału five $_{\mathrm{ACC}} \operatorname{men}_{\mathrm{GEN}} \quad \mathrm{was}_{3 S G . N E U T}$ selected ${ }_{\mathrm{ACC} / \mathrm{GEN}}$ to council faculty 'Five men were selected for the faculty council.'
(iii) Tom spotkał pięciu mężczyzn. Tom met five ${ }_{\mathrm{ACC}}$ men $_{\mathrm{ACC}}$
'Tom met five men.'
(iv) Tom nie widział pięciu mężczyzn.
Tom not see five $_{\mathrm{GEN}}$ men $_{\mathrm{GEN}}$
'Tom did not see five men.' 

b) (tamte) siedem/wiele kobiet weszło do budynku. those $_{A C C . P L}$ seven $_{A C C}$ many women GEN.FEM.PL $_{\text {entered }}$ SSG.NEUT $_{\text {to }}$ to building 'Those seven/many women entered the building.'

Yet another puzzle in accounting for agreement facts emerges in the context of adjectival predicates and participles found with quantified subjects (QPs) as the predicate/ participle may optionally occur in accusative or genitive, which indicates agreement either with the numeral or the nominal, e.g., (2). ${ }^{2}$
(2) Pięć kobiet byto wybrane/wybranych do rady nadzorczej. five $_{A C C}$ women $_{\text {GEN.PL }}$ was $_{3 S G . N E U T}$ chosen $_{3 P L . A C C / 3 P L . G E N}$ for board supervisory 'Five women were chosen for the supervisory board.'

Interestingly, in other related languages, for instance in Russian, agreement with quantified subjects is optional, e.g., (3a); however, once at least one element of the phrase is nominative, then only a full agreement becomes felicitous, e.g., (3b).
(3) a) Pjat' devušek rabotali/rabotalo tam. (Russian) five $\operatorname{girls}_{G E N . P L}$ worked $_{P L S G}$ there 'Five girls worked there.'
b) Èti pjat' devušek rabotali/*rabotalo tam. these $_{N O M}$ five $\operatorname{girls}_{G E N . P L}$ worked $_{P L / S G}$ there 'These five girls worked there.'

The peculiarities of agreement patterns in these languages have led us to resume a discussion of different facets of agreement, but this time, in the light of a nanosyntactic approach to grammar (cf. Starke 2009; Caha 2009, 2010 inter alia) which seems to adequately capture problematic paradigms with GoQ.

\section{THE AGREEMENT PUZZLE}

In numerous attempts to account for agreement patterns it has been proposed that the form of the predicate, i.e., agreeing with the subject or default, i.e., $3_{\text {SG.NEUT }}$, depends on the structure of the quantified subject which can constitute either a DP or QP (e.g., Pesetsky 1982; Franks 1994, 1995; Pereltsvaig 2006). ${ }^{3}$ In another approach, Bošković (2006) submits that a division into QP/DP can be dispensed with in favor of

2 In oblique case positions, higher numerals, i.e., $\geq 5$, behave like typical adjectival modifiers, i.e., they agree in number gender and case with the modified noun, e.g.

$\begin{array}{llll}\begin{array}{l}\text { Nauczyciel wyszedt } \\ \text { teacher }\end{array} \text { left } & \text { with sedmioma } & \text { uczniami. } \\ \text { 'A teacher left with seven pupils.' } & \text { pupils }_{\text {INST }}\end{array}$

3 For a detailed discussion of DP/QP status of quantified phrases in Polish see Witkoś and DziubałaSzrejbrowska (2015). 
a distinction based on (abstract) case. He puts forward the idea that high numerals are ambiguous between case (nominative/accusative) and caseless forms, whereas nominative always correlates with a full agreement. Moreover, the numeral 'pjat' occupies the specifier position of a nominal functional projection FP and shows case properties in one syncretic form: ${ }^{4}$

(4) $\quad\left[{ }_{\mathrm{FP}} \mathrm{QP}\left[{ }_{\mathrm{F}}, \mathrm{F} \mathrm{NP}\right]\right]$

(5) pjat': a. nominative b. accusative c. caseless

According to Bošković (2006) nominative case marking entails full agreement (as in Chomsky 1995 and the T/Agr model). Moreover, Bošković provides example (3), repeated here as example (6), arguing that as soon as any element of the FP shows nominative the entire FP loses its ambiguity, it transpires as nominative and it triggers full agreement:

(6) a) Pjat' devušek rabotali/rabotalo tam.

(Russian)

five $\operatorname{girls}_{G E N . P L}$ worked $_{P L S G}$ there

'Five girls worked there.'

b) Èti pjat' devušek rabotali/*rabotalo tam.

these $_{N O M}$ five $\operatorname{girls}_{G E N . P L}$ worked $_{P L S G}$ there

'These five girls worked there.'

A corresponding pattern, however, is not found in Polish as none of the elements of the quantified phrase is nominative (the numeral is marked with ACC, the noun with GEN and the determiner with ACC or GEN). Thus, as predicted in (5), we always observe a default agreement in Polish, e.g.:

(7) a) Pięć dziewczyn *pracowaty/pracowato tam. (Polish) five $_{A C C} \operatorname{girls}_{G E N . P L}$ worked $_{P L S G} \quad$ there 'These five girls worked there.'

b) Te_tych pięć dziewczyn *pracowaty/pracowato tam. these $_{A C C . G E N P L}$ five $_{A C C} \operatorname{girls}_{G E N . P L} \quad$ worked $_{P L / S G} \quad$ there 'These five girls worked there.'

Considering (5), we propose to credit the difference between Polish and Russian to distinct cases on the QP subject. While in Russian the case of the high numeral (and certain quantifiers) varies between nominative and accusative, in Polish it is accusative. So Russian T can successfully probe for the $\varphi$-features of the subject QP when it shows the $\varphi$-features that would match T. In Polish, and in certain contexts in Russian, the high numeral appears in the subject position in the other structural case, accusative

4 This proposal corresponds to The Licensing Parameter from Franks (2002): Polish QPs are licensed only in accusative DPs; Russian QPs are licensed in accusative and nominative DPs; SC QPs are licensed in all case DPs. 
(cf. Franks 1994, 1995, 2002; Przepiórkowski 2004), which precludes agreement for $\varphi$-features with $\mathrm{T}:{ }^{5}$

(8) $\mathrm{T}_{\varphi / \text { default }} \leftrightarrow\left[\left[_{\mathrm{QP}[+ \text { acc }]} \mathrm{Q}[\mathrm{NP}]\right]\right.$

Following this imperfect Match, $\mathrm{T}$ defaults to $3_{\mathrm{SG} . \mathrm{NEUT}}$, which suffices to account for (7) above. However, we are still left with the issue of the optional participial and adjectival agreement: ${ }^{6}$

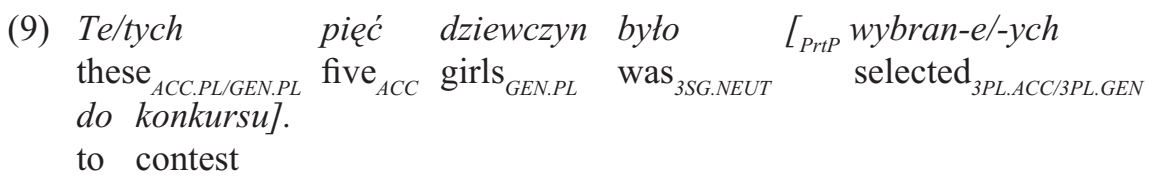

'These five girls were selected for the contest.'

\section{GENITIVE OF QUANTIFICATION: A BRIEF DIACHRONIC DISCUSSION}

An adequate analysis of agreement patterns with quantified subjects requires a proper understanding of the nature of numerals and changes they underwent. Considering that genitive is a typical adnominal case as well as the fact that in the past numerals $\geq 5$ used to be nouns with a feminine declension, the question that should be initially addressed is what category numerals are and what feature make-up they possess.

Historically, Polish higher numerals shifted from pure nominal (feminine declension) forcing their complement to appear in genitive to functional elements serving as

5 We follow Przepiórkowski $(1999,2004)$, who proposes that QPs are marked for accusative in the subject position on the basis of the following comparison, among others:
(i)
pięć
these $\mathrm{G}_{\text {GEN.FEM }} /$ these $_{\text {NOM?/ACC.FEM }}$ five NOM?/ACC.FEM 'These five women were standing.'
(tych/te)
$\left(\right.$ tych $\left./{ }^{*} c i\right)$
these ${ }_{A C C / G E N . M A S C}$ / these NOM.MASC? $_{\text {five }}$ NOM?/ACC/GEN.MASC
'These five men were standing.'
pięciu
kobiet
stato.
women $_{\text {GEN.FEM.PL }} \quad$ stood $_{3 \text { SG.NEUT }}$
mężczyzn
men $_{\text {GEN.MASC.PL }}$ stood $_{3 S G . N E U T}$

The common case form of the demonstrative (these) for both genders is accusative, on the assumption that its optional genitive reflects the placement of the demonstrative in the domain of the NP-complement and its subsequent raising to the domain of the numeral/quantifier.

6 The case of the demonstrative pre-quantifier, i.e., accusative or genitive, does not correlate with the case suffix on the adjective/participle, e.g.:

$$
\begin{aligned}
& \text { Te pięć dziewczyn zostało wybranych. } \\
& \text { these }_{A C C . P L} \text { five }_{A C C} \text { girls }_{\text {GEN.PL }} \quad \text { was }_{3 S G . N E U T} \text { selected }_{\text {GEN.PL }} \\
& \text { Tych pięć dziewczyn zostato wybrane. } \\
& \text { these }_{\text {GEN.PL }} \text { five }_{A C C} \operatorname{girls}_{G E N . P L} \text {, was } \text { 3SG.NEUT }_{\text {selected }} \text { ACC.PL } \\
& \text { 'These five girls were selected.' }
\end{aligned}
$$

For more examples see Przepiórkowski and Patejuk (2012). For a closer analysis of this case variability on the pre-quantifier, see Witkoś and Dziubała-Szrejbrowska (2016). 
modifiers agreeing in case with the nominal head. Rutkowski (2007: 240) presents the following comparison, e.g., pięć lat (five years).

\begin{tabular}{l|l|l} 
Case & OLD POLISH & PRESENT DAY POLISH \\
\hline Nominative & pięć lat & pięć lat \\
\hline Genitive & pięci lat & pięciu lat \\
\hline Dative & pięci lat & pięciu latom \\
\hline ACCUSATIVE & pięć lat & pięć lat \\
\hline InSTRUMENTAL & pięcią lat & pięcioma latami \\
\hline Locative & pięci lat & pięciu latach
\end{tabular}

He further proposes to capture the diachronic change in terms of a grammaticalisation procedure, whereby a higher numeral turns from a content category $\mathrm{N}$ to a functional category $\mathrm{Q}:^{7}$

$$
\begin{aligned}
& {\left[{ }_{D P} \mathrm{D}\left[{ }_{\mathrm{NP}} \text { pięć }_{\mathrm{N}}\left[{ }_{\mathrm{DP}} \mathrm{D}\left[\left[_{\mathrm{NP}} \text { lat }_{\mathrm{N}}\right]\right]\right]\right] \quad\right. \text { Old Polish }} \\
& {\left[_{D P} D\left[{ }_{Q P} \text { pięć }_{Q}\left[{ }_{N P} \text { lat }_{N}\right]\right]\right] \quad \text { Present Day Polish }}
\end{aligned}
$$

This diachronic change leads to both a simplification and complication of the structure of the Q-N relations. The structure is simplified from a bi-nominal frame, with a regular $\left[_{\mathrm{DP}} \mathrm{D}\left[\mathrm{NP}_{\mathrm{NP}} \mathrm{N}\right]\right.$ ] content (or a functional projection/lexical projection content) to a single nominal constituent headed by $\mathrm{N}$ but insulated by two functional categories $\left[_{\mathrm{DP}} \mathrm{D}\left[_{\mathrm{QP}} \mathrm{Q}\left[_{\mathrm{NP}} \mathrm{N}\right]\right]\right] .{ }^{8}$ The latter structure becomes more complicated than it used to be. In terms of the feature composition of the $\mathrm{N}$ and $\mathrm{Q}$ categories, the relevant difference correlates with the presence or absence of the [ person] feature (cf. 13b) below. Consequently, we propose that the activation of this feature on the higher numeral by $\mathrm{T} / \mathrm{v}$ is a residue of the diachronic change that took place in the grammar of Polish: activation of this feature finds its source in the past when higher numerals were nouns (cf. 11). ${ }^{9}$

7 Although at some point in our discussion we present nominal structures containing a DP layer, we refrain from taking stance in a discussion on DP/NP status of nominals. What is crucial for us is that nominals in Polish cannot be bare NPs with modifiers in the adjunct positions (contra Bošković 2005). Whether the nominal projection is actually a DP or any other XP (cf. Willim 2000 proposing that Polish nominals are KPs rather than DPs) does not affect the essence of our proposal.

8 For another recent discussion of a historical development of higher numerals in Polish see Miechowicz-Mathiasen (2014).

9 Other accounts of the Genitive of Quantification endorse the dual (adjectival/nominal) character of Slavic numerals (quantifiers) but typically leave it without much discussion (cf. Bošković 2006) or credit its properties to different levels of grammatical representation (D-Structure vs. S-Structure in GB-style theories, cf. Babby 1987 and Franks 1994, 1995). 
(13) a) Adjective [ ${ }_{\mathrm{u}}$ umber] [ ${ }_{\mathrm{u}}$ genger] $\left[_{\mathrm{u}}\right.$ case $]$

b) Numeral $\left[{ }_{u^{*}}\right.$ number $]\left[{ }_{u^{*}}\right.$ gender $]\left({ }_{i}\right.$ person $\left.]\right)\left[{ }_{u}\right.$ case $]$

c) Noun $\left[_{i}\right.$ number $\left[_{i}\right.$ gender] [person] $\left[_{u}\right.$ case $]$

(14) The construction of the Genitive of Quantification is a residue of an earlier, fully nominal stage in the diachronic development of Polish numerals.

Its residual character is clear from its distribution, as it occurs only in a subset of QP environments. It is like the residue of V-2 in English (captured through the feature composition of C), showing only in interrogative and emphatic constructions. Though the [ person] feature on a numeral $\geq 5$ in Present Day Polish is activated by $\mathrm{T} / \mathrm{v}$ the structure is not bi-nominal as in (11); in other words, the source of the idiosyncrasy of the GoQ construction stems from the fact that the constituent structure of the frame is modern, i.e., (12), but the feature content of numeral from a previous stage is invoked. The in-between pattern in (13b) reflects the Polish and Russian GoQ constructions, where in structural case contexts the high numeral, otherwise adopting the guise of an adjective, puts on the guise of a nominal when matching a finite $\mathrm{T} / \mathrm{v}$ probe. ${ }^{10}$ The change of the guise is due to the activation of an otherwise dormant feature [ person]. We also submit that this derivational nominal construct is defective, as it has an impoverished case menu in that both structural cases are lumped into one: accusative.

\section{THE NANOSYNTACTIC ACCOUNT OF GENITIVE OF QUANTIFICATION}

A sheer number of analyses of the GoQ leads one to believe that this construction serves as a litmus paper for all emerging theories in Slavic linguistics. The number of analyses attempting to explain case properties and distribution within quantified phrases involves a considerable dose of 'look-ahead' or a number of countercyclic operations. One of the most typical technical devices involving countercyclic operations is the use of the GB distinction between Deep and Surface Structure operations, where the latter repairs, or fills in the procedural gaps left by the former, with the final grammatical representation in sight. Another popular move to take agreeing numerals $(<5)$ to be APs and numerals $\geq 5$ to be heads, which probably violates No Tampering (cf. Chomsky 2000, 2001) when it is to be determined. In Babby (1987) case is assigned by the external head to the maximal projection, i.e., NP, which subsequently spreads to other constituents of the phrase. When Q is present in the structure, in nominative and accusative contexts, it assigns genitive which percolates down to other constituents of the nominal phrase blocking case assignment from the outside. When the external head assigns one of the oblique cases the presence of $\mathrm{Q}$ does not hinder case spreading as the inherent case overrides the structural one, hence homogeneous syntax. Some other works, e.g., Franks $(1994,1995)$ stresses the parametric variation to numeral

10 On the nominal status of higher numerals see also Babby (1987), Greenberg (1978), Corbett (1978a,b) and Caha $(2012,2013)$ among others. 
phrases, i.e., in Russian they are either NPs or QPs, in SC they are NPs and in Polish they present the characteristics of both NPs and QPs. In accusative contexts they are QPs. Przepiórkowski (1999), similarly to Franks, assumes that a higher numeral bears accusative and constitutes the head of the phrase. The noun becomes then its argument, i.e., the subject. This analysis involves considerable look-ahead. In Rutkowski (2002) agreeing numerals, i.e., $<5$, are viewed as adjectival and thus are introduced in the position of [spec, NP], e.g., (15a), whereas higher numerals are placed in the head position of QP, e.g., (15b):

$$
\begin{aligned}
& \text { a) } \left.\int_{\mathrm{DP}}\left[{ }_{\mathrm{D}}, \mathrm{D}\left[_{\mathrm{QP}}\left[{ }_{\mathrm{Q}}, \text { pięć }\left[_{\mathrm{NP}}\left[\mathrm{L}_{\mathrm{N}}, \text { osłów }\right]\right]\right]\right]\right]\right] \\
& \text { 'five donkeys' } \\
& \text { b) }\left[_ { \mathrm { DP } } \left[\left[_{\mathrm{D}}, \mathrm{D}\left[_{\mathrm{QP}}\left[\left[_{\mathrm{Q}}, \mathrm{Q}\left[_{\mathrm{NP}} \text { dwie }\left[_{\mathrm{N}}, \text { kobiety }\right]\right]\right]\right]\right]\right]\right.\right. \\
& \text { two women' }
\end{aligned}
$$

Likewise, Bailyn (2004) proposes that the numeral, depending on its value, occupies either the specifier or the head position of QP. The choice of its place in the structure is made at the $\mathrm{vP}$ level. The assignment of genitive to the noun is contingent on the position of the numeral, i.e., when it is placed under Q, the case is absorbed and homogenous pattern results, e.g., (16a). With the numeral in [spec, QP], Genitive of Quantification is obtained, e.g., (16b).This relation is formed countercyclically, only after the verb has been merged and the verbal projection has enveloped the NP.

(16) a) The homogeneous pattern:

$\left[_{\mathrm{VP}}\left[\left[_{\mathrm{V}}, \mathrm{V}\left[_{\mathrm{QPinstr}}\left[\mathrm{L}_{\mathrm{Q}}\right.\right.\right.\right.\right.$, pięcioma $\left[_{\mathrm{NPinstr}}\left[\left[_{\mathrm{N}}\right.\right.\right.$, językami $\left.\left.\left.\left.\left.]\right]\right]\right]\right]\right]$

'(with) five languages'

b) The heterogeneous pattern:

$\left[_{\mathrm{VP}}\left[{ }_{\mathrm{V}}, \mathrm{V}\left[_{\mathrm{QPnom} / a c c}\right.\right.\right.$ pięć $\left[, \varnothing\left[_{\mathrm{NPgen}}\left[\left[_{\mathrm{N}}\right.\right.\right.\right.$, jezzyków $\left.\left.\left.\left.\left.]\right]\right]\right]\right]\right]$ 'five languages'

Finally, in Bošković (2006, 2013) numerals are lexically specified as either adjectival, hence APs, or quantifiers, i.e., QPs, with agreeing numerals, i.e., $<5$, occupying the adjunct position of NP, i.e., [FP [F' F [NP AP [N' NP] ]] and Quantifiers, i.e., $\geq 5$ placed in the specifier position of FP, i.e., [FP QP [F' F [NP [N' NP] ]]]. Genitive case is assigned by the $\mathrm{F}$ head but only when the specifier position of FP is filled by the QP.

Although each of these analyses provide an interesting insight into the nature of QPs, they do not address other intricacies of quantified phrases. Thus, we would like to outline a solution in the spirit of nanosyntax.

The major claim of the nanosyntactic approach is that the sub-word/morpheme level processes are treated in parallel with core syntactic phenomena. In the syntax of nominals, the nanosyntactic model (cf. Starke 2009; Caha 2009, 2010; Taraldsen 2009) provides means to derive various case patterns allowing for movement of the entire NP within the set of case projections (split KP). The analysis of the position of the nominal 
head with respect to its satellites (demonstratives, numerals, adjectives) is based on Cinque 2005 which restricts certain types of movement, i.e., rightward and downward movement are forbidden, and determines which chunk of the structure can be moved, i.e., the one with the nominal head. The essential component of the analysis is that particular cases are matched to the functional projections within an articulated Kase Phrase which belongs to the extended projection of the noun (NP). The nominal, in order to acquire a given case, i.e., a proper case suffix, merges in the structure uninflected, and in the course of a derivation moves to the position c-commanding a given case. In our proposal that is the specifier position of a particular case projection. Movement of the nominal is initiated by the probe and its position in the case sequence is determined by language specific constraints. The case sequence and ordering of cases is uniform across languages and is stated in the Universal Case Contiguity (Blake 1994; Caha 2009), e.g., (from Caha 2010: 7): ${ }^{11}$

$$
\text { comitative }>\text { instrumental }>\text { dative }>\text { genitive }>\text { accusative }>\text { nominative [noun] }
$$

As example (17) shows, nominative and accusative are placed as the lowest cases in the sequence, which indicates that they are the least marked cases set apart from oblique ones which are usually morphologically more complex (Caha 2009). ${ }^{12}$ Also, case syncretisms are predicted to occur on adjacent cases/nodes. Case suffixation follows either an analytic pattern (pied-piping), or a synthetic one. In the former the nominal core (NP) moves successive cyclically to the specifier position of each intermediate case and pied-pipes this functional sequence to its final destination within KP. In the latter the nominal core moves in a single step to its final specifier position (direct movement) and no pied-piping is evident morphologically. In general the nanosyntactic approach to case predicts that nominals in Slavic wear their cases on the sleeve in the sense that the NP moves overtly to a given position within the Kase Projection, which constitutes the external functional projection layer of the nominal constituent.

\subsection{Case Projection Sequence and Polish Nominals: Derivation of Genitive of Quantification}

In our analysis of Polish nominals we take the noun to be the core element of the phrase, whereas demonstratives, adjectives or numeral quantifiers are located in specifiers and adjoined positions:

11 The case sequence in (17) corresponds to the sequence of NP-external probes that license particular cases, with $\mathrm{T}$ licensing nominative, To accusative, $\mathrm{D}$ (adnominal) genitive, etc.: ... $>\mathrm{D}>$ $\mathrm{To}>\mathrm{T}$. A proposal along these lines is put forward in Svenonius (2004).

12 The case hierarchy in (17) overlaps to a large degree with the hierarchy proposed in Babby (1987), where the leftmost cases override the rightmost cases on the assumption that lexical properties must be satisfied before the syntactic ones (Principle of Lexical Satisfaction), i.e., Lexical case $>$ GenQ $>$ Nom/Acc.

The sequence of case preference is to be taken representationally, rather than derivationally, so Babby's case overriding is not Pesetsky's (2013) case overwriting. 
(18)

$$
\cdots\left[{ }_{Q P} \operatorname{Num}\left[{ }_{Q}, F_{Q}\left[{ }_{N P} \operatorname{Dem}\left[{ }_{N P} \operatorname{Adj}\left[{ }_{N P} N\right]\right]\right]\right]\right.
$$

$\mathrm{KP}$, taking active part in the licensing of case, is split into particular case projections and belongs to the extended functional projection of a noun, i.e., there is one articulated KP per a nominal core and its modifiers in Polish. The NP headed by the noun with $[+\mathrm{N}]$ feature, moves up to a given position within the case projection sequence, i.e., to the specifier of what we call Nominative Phrase (NomP), Accusative Phrase (AccP) or other case projections where a given case is licensed. The exact motivation for this movement is the need for a successful Spell-Out of a given case suffix, in line with Caha $(2009,2010)$ :

a)

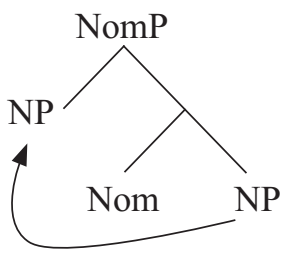

b)

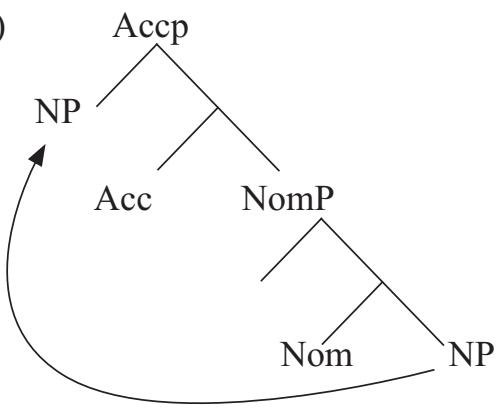

The classic nanosyntactic literature devotes little attention to the relation between the extended projection of the nominal and the split KP and other components of the derivation, becoming liable to the charge of 'look-ahead' (cf. Caha 2012, 2013 on numerals). We attempt to incorporate the detailed syntax of case with the syntax of larger components including the nominal (the phrase and the clause) in a manner compatible with the phase theory (e.g., Chomsky 2000, 2001, 2008). ${ }^{13}$ Thus in example (20) we present an exemplary derivation with a QP selected by a head, a verb or a preposition, imposing dative on its argument (the homogeneous pattern). We assume that the case paradigm of the higher numeral is defective in that its case projection sequence is truncated at the bottom and NomP is absent, with accusative left as the only structural case.

$\begin{array}{lll}\text { (20) a) tym } & \text { sześciu paniom } \\ \text { these }_{D A T} & \operatorname{six}_{D A T} & \text { ladies }_{D A T}\end{array}$

13 We propose one KP per a nominal projection, i.e., the head noun and its modifiers, which is a crucial difference between Caha's $(2009,2010)$ account, in which projection of every declining element is topped with a separate KP, and ours. This way we can adequately represent the structure of quantified phrases which have changed from a binominal into a single phrase, i.e., a single set of case projections over the QP is a result of the diachronic change discussed in Rutkowski (2007), here examples (11) and (12). 
b) activation of DatP

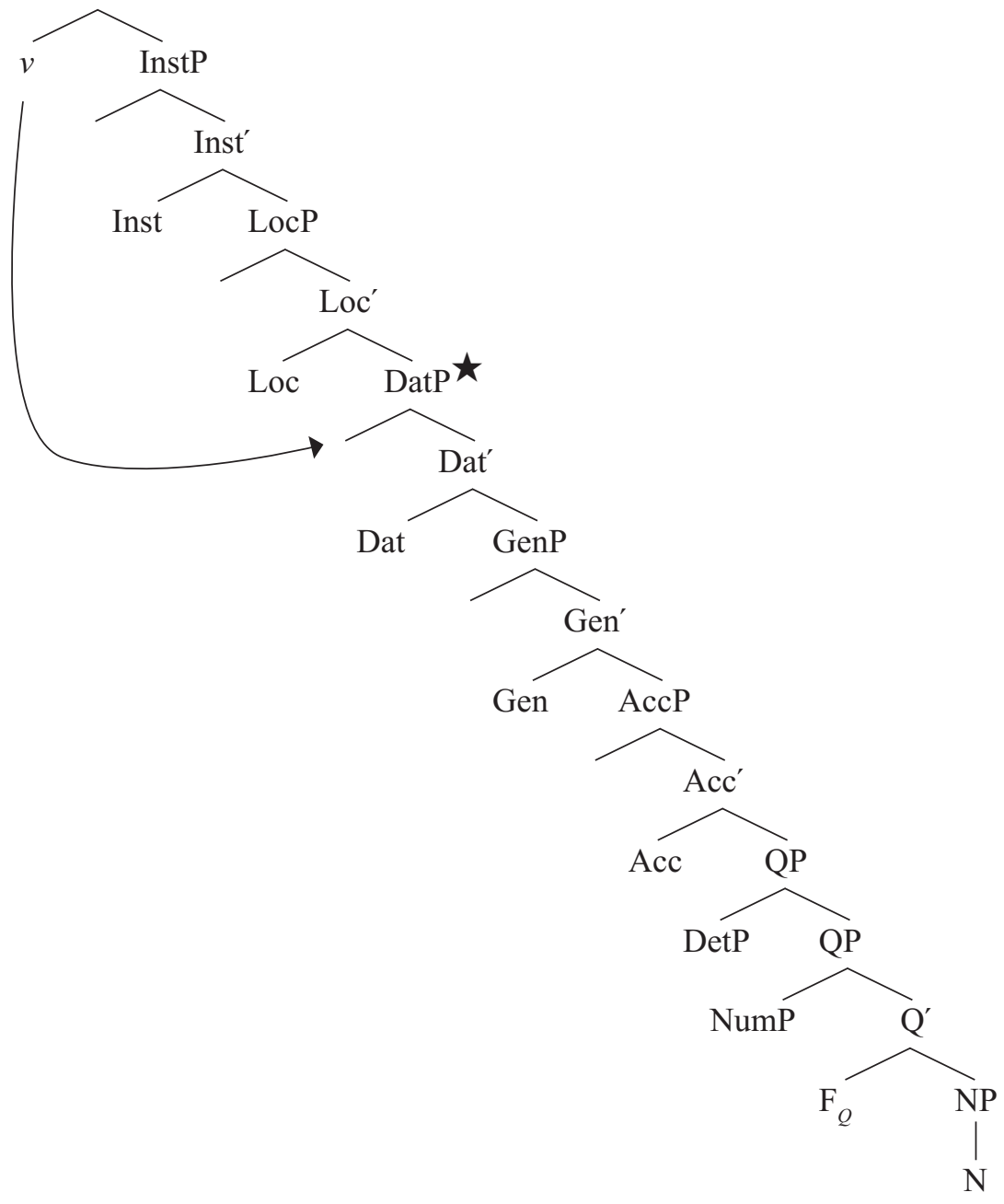


c) movement of QP to DatP

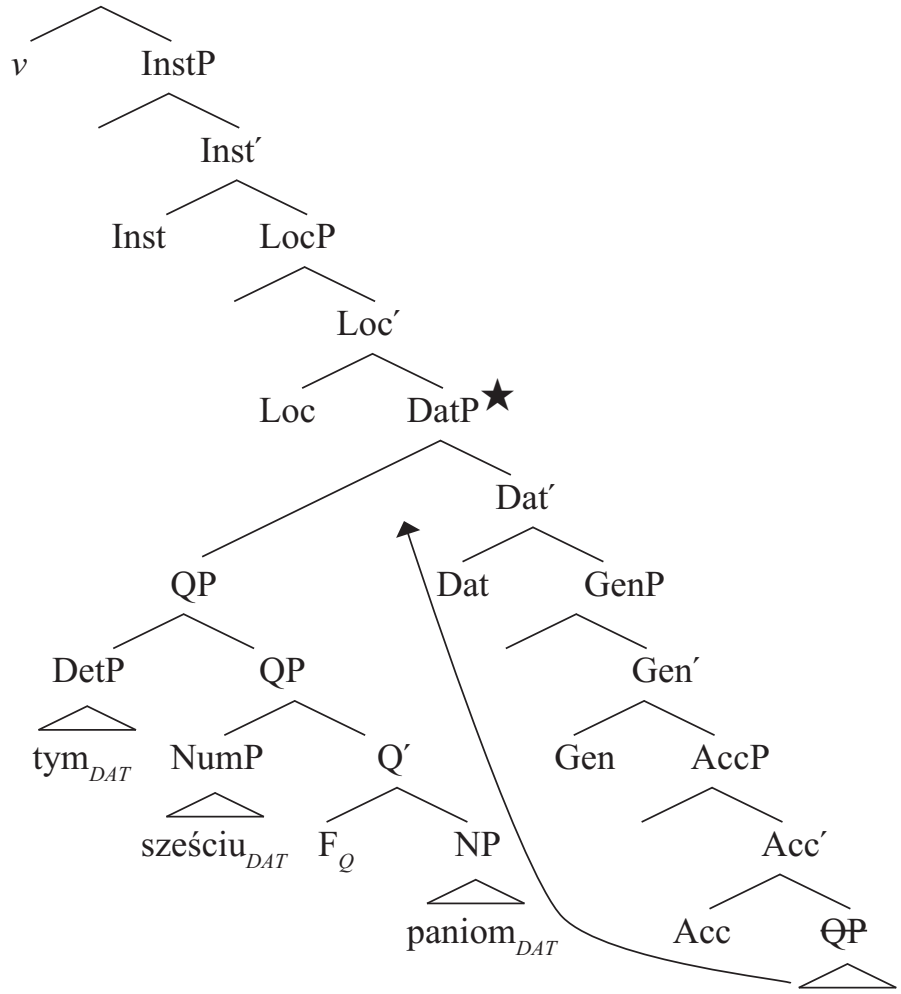


d) deletion of the case projection sequence above DatP

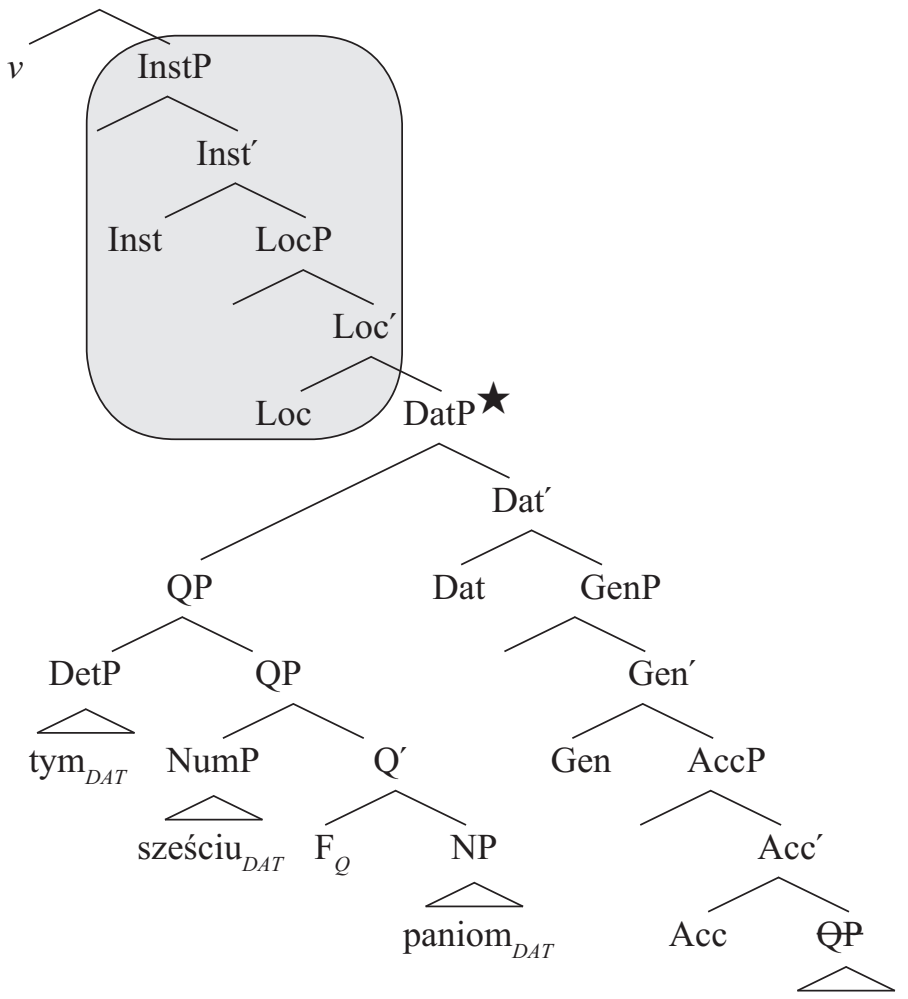

Upon the merger of a (quantified) nominal with a full inventory of cases with the probe, $\mathrm{v}$ or $\mathrm{P}$, selecting for an argument in a particular case, a relevant case projection becomes activated (20b) and attracts the QP (20c). The movement of QP to [spec, Dat] follows from the postulate of Spell-Out driven movement, whereby the section of the case projection sequence spells out as the dative suffix. As the result, the whole QP phrase moves to the specifier of the Dative Phrase where all the elements in the extended projection of $\mathrm{N}$ (the bearer of the full set of $\varphi$-features) become marked dative. In the presented derivation, contrary to the major tenet of nanosyntax, the case head affects the entire phrase and the suffix must be appended not only to the final nominal position in the phrase but it must also spread onto the numeral/adjective/demonstrative. At this time we can only propose that the derivational stage in (20) takes place in narrow syntax and the nominal sequence is then marked to be realized with morphological 
content on the PF branch. ${ }^{14}$ After the part of a derivation in which all the elements of the QP are secured with the right case, other higher and unused projections within split KP become elided, cf. (20d).

In case of the Genitive of Quantification, the derivation becomes slightly more complex as the quantifier and its nominal complement bear different cases, i.e., accusative and genitive respectively. In order to account for this case mismatch we make two crucial assumptions: (i) within a simple case projection sequence all cases are distinct from one another and their projections are transparent to probing/attraction from higher case heads, without causing minimality/intervention effects; (ii) as the internal morphological composition of certain cases is analytic (i.e., the case suffix of a case higher in the sequence in (20) includes the suffix of a lower case) successive cyclic movement within KP is an option. ${ }^{15}$ In such a movement step the Accusative Phrase (accusative marker) can be pied-piped with the NP projection as one constituent. These two elements become instrumental in our account of GoQ. At a certain point in the derivation the $\mathrm{v}-\mathrm{V}$ complex accesses the case projection sequence with a full set of $\varphi$-features to value it as accusative and have its own complete $\varphi$-feature set valued. At the same time $\mathrm{Q} / \mathrm{F}_{\mathrm{Q}}$ becomes activated as an adnominal genitive marker and genitive within the split KP becomes activated, see (21b). In the context of nanosyntax we propose the following derivation, where multiple movements within a single KP are crucial. A single case projection sequence over the QP is a result of the diachronic change discussed in Rutkowski (2007).

$$
\begin{array}{lll}
\text { a) Zobaczyłem pięć } & \text { kobiet. } \\
\text { saw }_{I S G} \text { five }_{A C C} & \text { women }_{\text {GEN.PL }} \\
\text { 'I saw five women } &
\end{array}
$$

14 By doing so we subscribe to the proposal spelled out in Pesetsky (2013: 99-102) concerning the spread of case within a particular case-marked domain through morphological means. His particular technical solution relies on the use of prototype categories that become sisters to case bearers and has two interesting aspects. First, a prototype $x^{*}$ is realized adjacent to the smallest element dominated by the sister of the case licensor. Second, the prototype is not necessarily realized as word-level morphology, but is realized at the lowest structural level that the language and construction permit, which is sometimes phrase-level. In the system developed here, case is appended to the constituent that a given case head attracts and forces it to become its specifier. The lexical realization (for instance spread within this constituent) is determined by the morphology of a given language.

15 Various elements of the same nominal sequence are distinct from each other in the sense of Relativized Minimality (Rizzi 1990) and do not cause intervention effects with respect to one another's participation in Match, Agree and Move for case. Regarding case licensing on $\mathrm{N}$ it may involve pied-piping of its dependents in accordance with Cinque (2005) and the study of permutations in DP/NP internal word orders involving demonstratives, numerals and adjectives, which share a number of properties with case marking viewed as a result of syntactic movement 
b) NumP is activated as a nominal element with a full set of $\varphi$-features and enters into a probe/goal relation with $\mathrm{v}$. As a result AccP is activated.

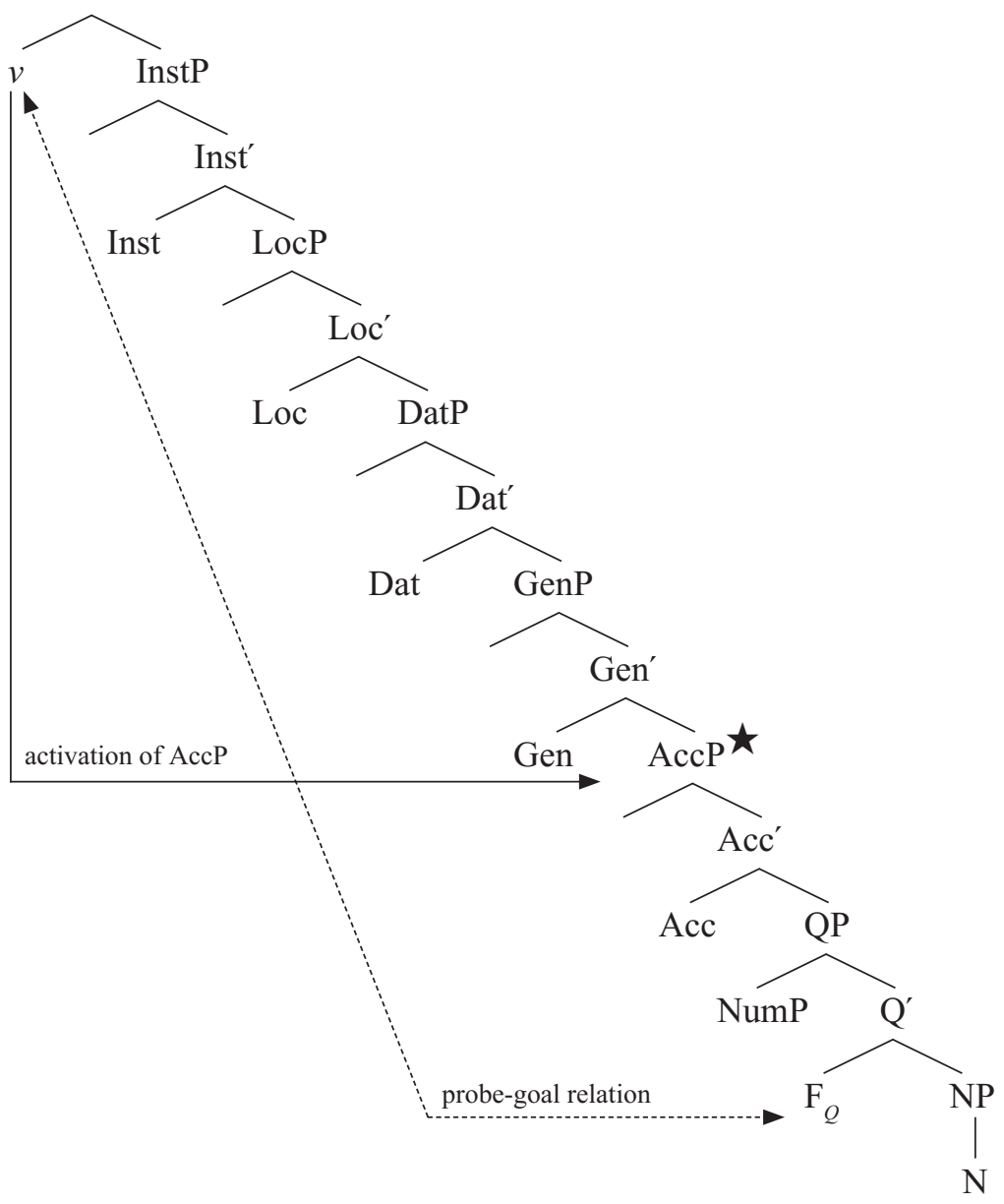


c) QP moves to [spec, Acc].

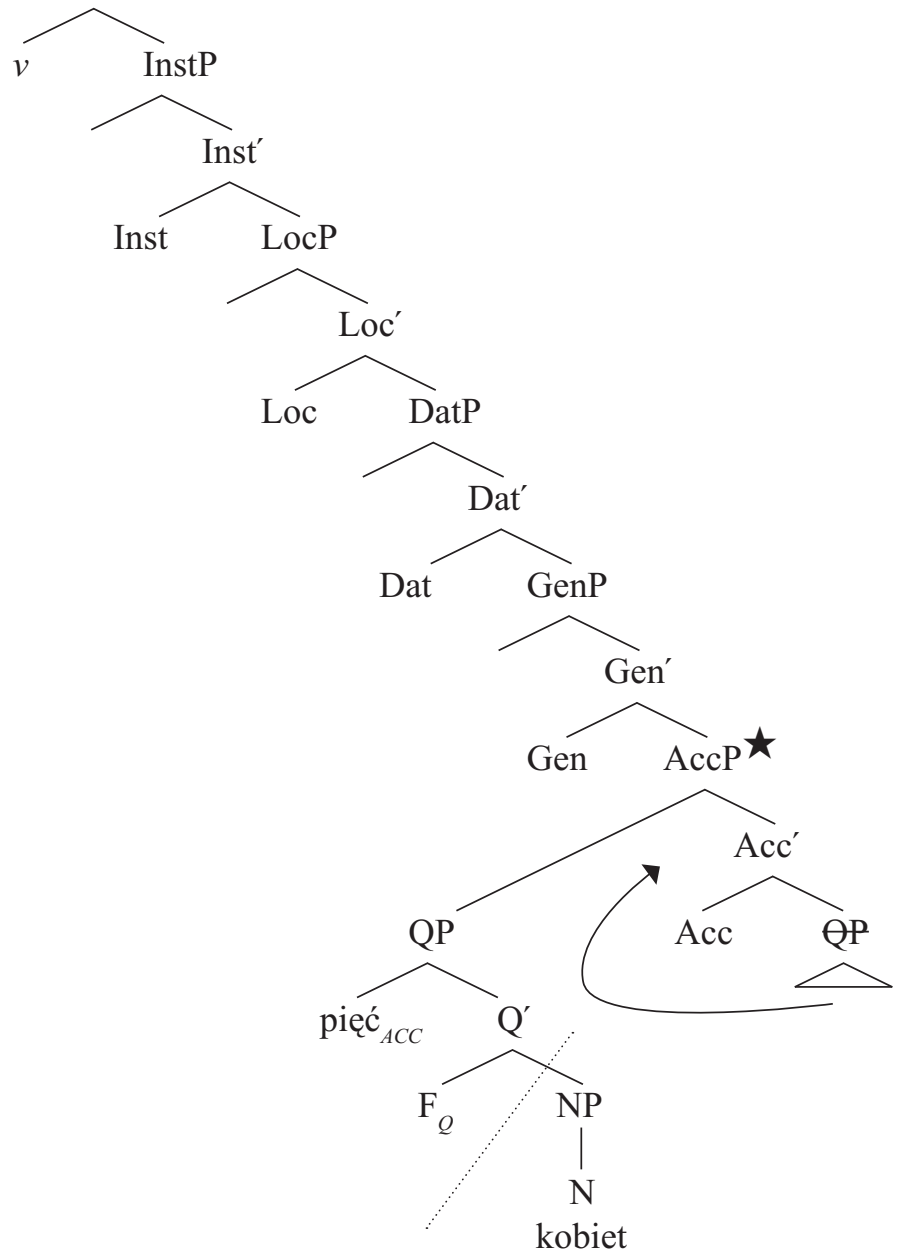


d) NP enters into a probe/goal relation with Gen across QP.

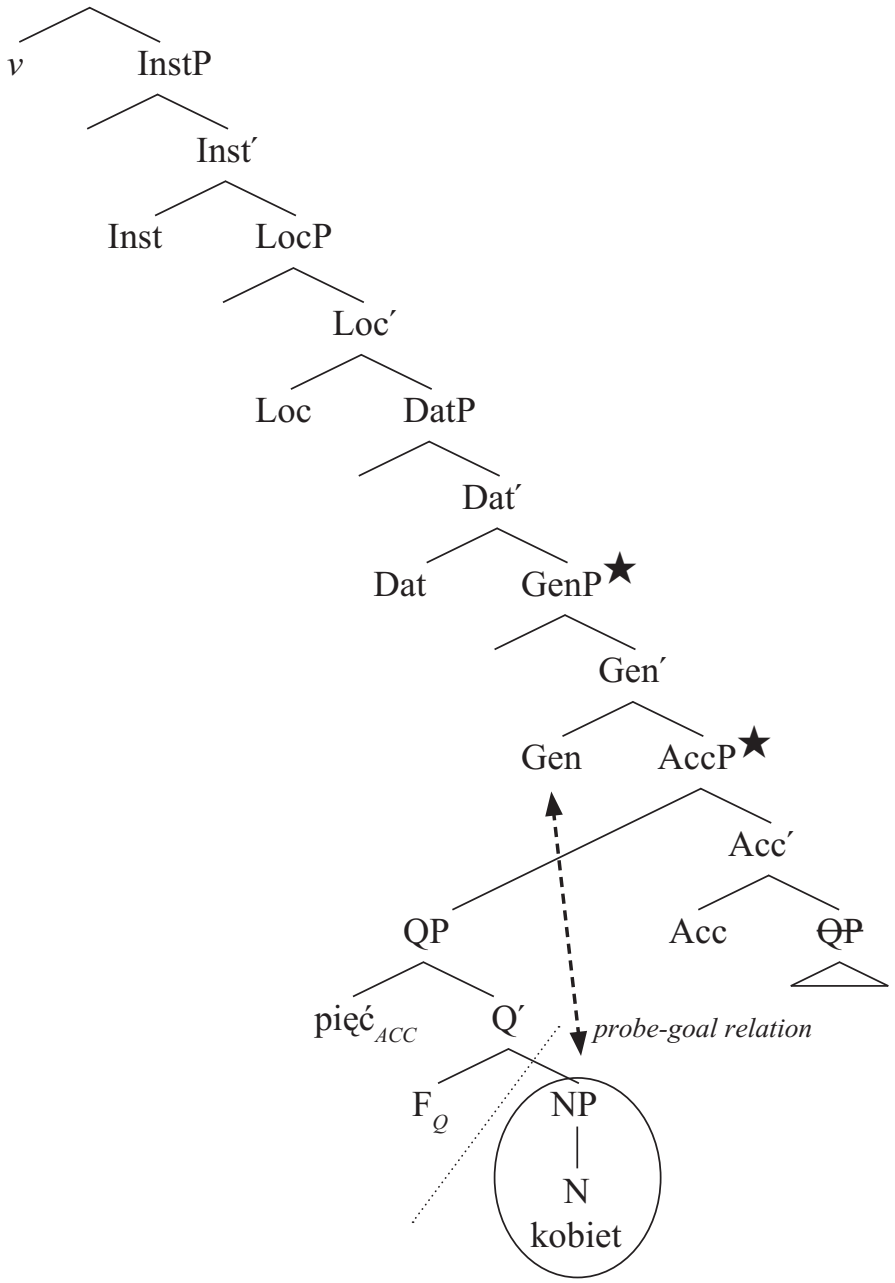


e) NP moves to [spec, Gen] pied-piping [AccP QP] on top. The remaining case projections become deleted.

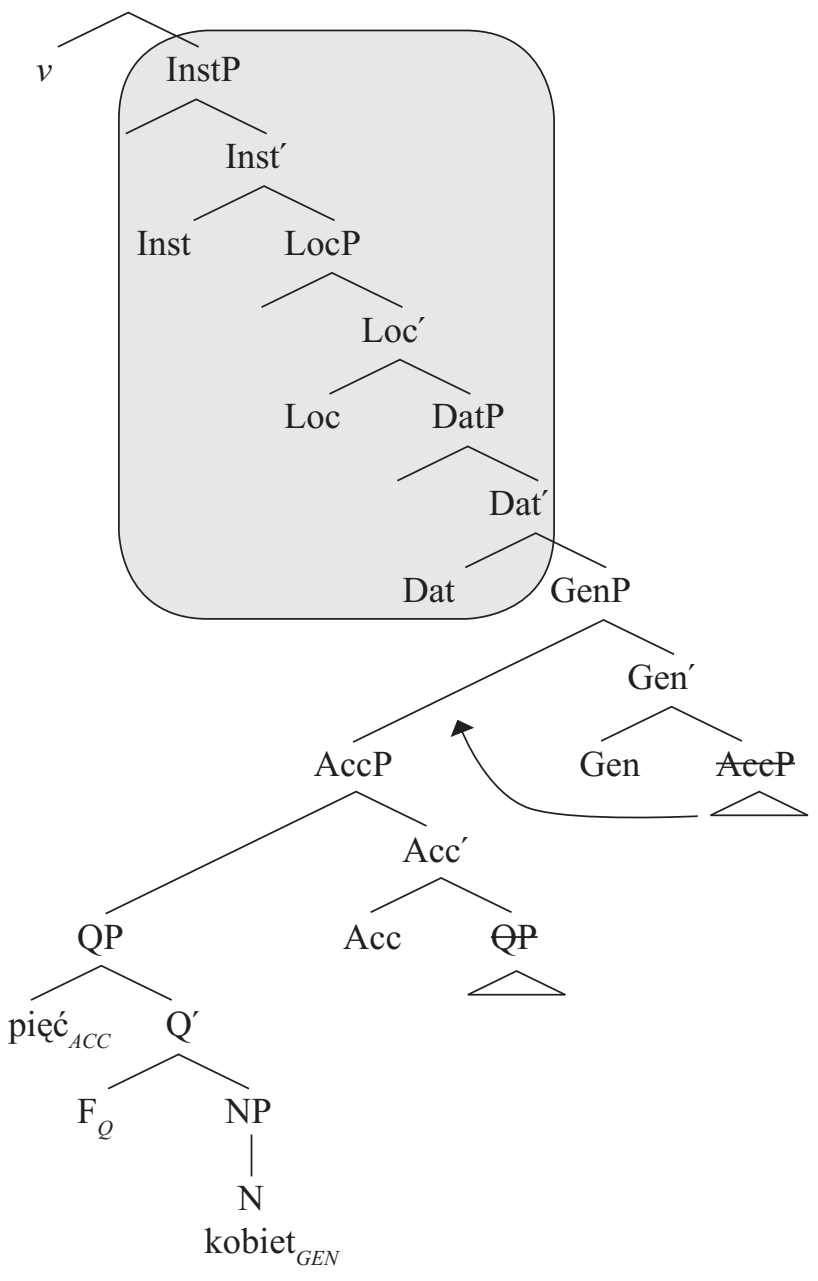


In the structure presented in (21) the nominal phrase, consisting of a noun, its modifiers and the extended function projection (split KP), is selected as an argument. Then $\mathrm{v}$ accesses the QP, gets involved in the relation Agree/feature sharing with it and activates AccP in the case projection sequence, cf. (21b). At the same time the higher numeral NumP is accessed by $\mathrm{v} / \mathrm{T}_{\mathrm{o}}$ and its [person] feature becomes activated, leading to the default setting of all other $\varphi$-features and turning NumP into an appropriate goal for $\mathrm{v}$, as well as allowing it to license a nominal dependent, cf. (21b). As a consequence, the entire phrase (QP including NumP) moves to the position within split KP to appear in the case imposed by the external selector, e.g., $v$ makes a QP move to [spec, Acc] (21c).${ }^{16}$ The NP is pied-piped but accusative case is not transmitted to the NP complement which still requires another case. ${ }^{17}$ The exceptional nature of this derivation lies in the fact that at this stage of the derivation a single extended functional projection of $\mathrm{N}$ (KP) must service two heads bearing independent sets of $\varphi$-features: the new-born $[+\varphi]$ NumP and the original $[+\varphi] \mathrm{N}$. The relation between these two follows an otherwise attested path: a c-commanding nominal $[+\varphi]$ head forces the other nominal $[+\varphi]$ head (and its dependents within the same maximal projection) to appear in genitive. This is technically achieved in a Last Resort mode by the Genitive Case Projection, which is activated and accesses the NP across the case marked NumP, cf. (21d). Several reasons come to mind as to why the derivation should allow for this (non-local) relation. First, it takes place within the same extended nominal sequence and no other probe external to the QP is involved. Second, NumP is transparent to the probing from Gen to NP, as its case feature has already been valued. Likewise, the Accusative Phrase is transparent to the attraction of NP by the genitive. Moreover, the Accusative Phrase including NumP is pied-piped in the movement of the NP to its genitive-licensing position, cf. (21e). Third, the derivation in (21) bears the flavor of Richards' 1998 Principle of Minimal

16 As pointed out by the reviewer the activation of a person feature and turning a numeral into an element of category $\mathrm{N}\left(\mathrm{Q}_{\mathrm{N}}\right)$ which is able to value an external case probe (little $\mathrm{v}$ ) as a closer, c-commanding and more minimal goal violates the Inclusiveness Condition. Although we acknowledge this shortcoming of the analysis, it actually follows from the nature of higher numerals which are hybrid, in-between category. Moreover, in order to account for properties of higher numerals either the Inclusiveness Condition is violated or a look-ahead is observed.

17 We must forcefully state that we clearly distinguish between two superficially similar phenomena: case composition and case stacking. The former is ubiquitous in nanosyntax and refers to the morphological composition of case suffixes and is instrumental in establishing the case sequence in example (17) above. It does not presuppose, and must be distinguished from, case stacking understood as a multiple procedure of case marking of one and the same NP set against a number of case licensing heads in the same derivation (cf. Richards 2007; Pesetsky 2013). Case stacking typically involves case overwriting, a procedure of nullifying an earlier case relation [head ${ }_{1}$ $\mathrm{NP}$ ] by a later relation $\left[\mathrm{head}_{2}-\mathrm{NP}\right]$, with or without a morphological trace of the earlier relation showing on the NP. Our account does not presuppose case stacking; on the contrary, we assume that each head bearing a full set of $\varphi$-features (and its extended projection including dependents, i.e., adjectives and intensifiers) participates in only one case relation per derivation:

Each head bearing a full set of $\varphi$-features (and its extended projection including dependents, i.e., adjectives and adjuncts) participates in only one case relation per derivation. 
Compliance: ${ }^{18}$ within one and the same set of case projections a more local relation is established first (Acc - NumP) before a less local relation is established (Gen - NP). Our account presupposes that there is no case overwriting in Polish (and related languages) and its morphology displays an application of a Genuine Single Suffix Rule: what you see is what you get: Elements placed within QP receive accusative, while elements placed within NP receive genitive. ${ }^{19,20}$

\section{SOLVING THE AGREEMENT PUZZLE}

The nanosyntax inspired account of GoQ leads to a relatively straightforward account of the troublesome agreement patterns mentioned in ex. (2) and (9), repeated below for convenience as (23), with (22) showing the relevant section of the representation:

(22) a) T...Part(iciple)... [ $\left[_{\mathrm{GenP}}\left[{ }_{\mathrm{AccP}}\right.\right.$ te pięć kobiet $]$ Gen $]$

b) $\mathrm{T} / \mathrm{Prt} \Rightarrow$

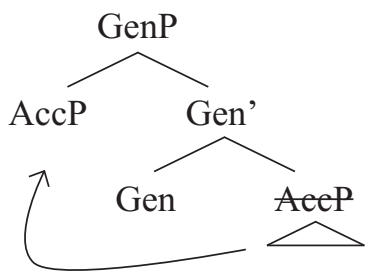

$\begin{array}{lllll}\text { (23) Te/tych pięć kobiet } & \text { byto } & \text { wybrane/wybranych } & \ldots \\ \text { These }_{A C C / G E N} \text { five } & \text {... } & \text { women } \\ \text { GEN.PL } & \text { was }_{3 S G . N E U T} & \text { chosen }_{3 P L . A C C / 3 P L . G E N} & \\ \text { 'Five women were chosen .....' } & & & \end{array}$

The relative configuration of GenP and AccP in (22b) is such that the probe Part is equidistant from both GenP and AccP, on the following assumptions in Pesetsky and Torrego (2001).

18 Principle of Minimal Compliance: For any dependency D that obeys constraint C, any elements that are relevant for determining whether $\mathrm{D}$ obeys $\mathrm{C}$ can be ignored for the rest of the derivation for purposes of determining whether any other dependency D' obeys C (Richards 1998: 601).

19 We assume that the morphological component on the PF branch of grammar can correctly deal with the marking of both NumP in spec, QP with accusative and N (NP) with genitive, on the assumption that both head/spec relation (accusative) and linear adjacency (genitive) are legitimate relations for morphology to operate on.

20 One of the consequences of our account is that the default adnominal case must be higher within the KP sequence than the initial structural case absorbed by the nominalized numeral:

The default adnominal case postulate: The default adnominal case projection is placed higher in the case hierarchy than structural cases. 
(24) a) Attract Closest: If a head $\mathrm{K}$ attracts feature $\mathrm{F}$ on $\mathrm{X}$, no constituent that bears $\mathrm{F}$ is closer to $\mathrm{K}$ than $\mathrm{X}$.

b) Closeness: $\mathrm{Y}$ is closer to $\mathrm{K}$ than $\mathrm{X}$ if $\mathrm{K}$ c-commands $\mathrm{Y}$ and $\mathrm{Y}$ c-commands $\mathrm{X}$.

In their discussion of the that-trace effect, they argue that in the configuration below both the specifier of $\mathrm{T}$ and the projection of TP can delete the (same) feature uT on C:

(25) We know $\left[_{\mathrm{CP}}\left[\mathrm{C}_{\mathrm{uT}}\right]\left[_{\mathrm{TP}}\left[\right.\right.\right.$ the student $\left._{\mathrm{uT}}\right] \mathrm{T}\left\{\right.$ that $\left._{\mathrm{iT}}\right\}\left[_{\mathrm{VP}}\right.$ bought the book $\left.\left.]\right]\right]$

The notion of closeness is a crucial component of the relations of not only Attract (and Move) but also Match and Agree in the phase-based theory (Chomsky 1995, 2000, 2001, 2008). For instance, the probe is supposed to match and agree with the closest potential goal. In (20) GenP dominates AccP, so it does not c-command it, and while AccP c-commands Gen, the same label as the label on Gen is present on GenP. In the context of our discussion of GoQ in the nanosyntax inspired framework, the structure of relevant QPs in Polish and Russian looks as follows:

(26) a) $\mathrm{T}\left[\left[_{\text {GenP }}\left[\left[_{\mathrm{NomP}} \ldots\right] \ldots\right.\right.\right.$ Gen $]$ Rus.

b) $\mathrm{T}\left[\left[_{\mathrm{GenP}}[\mathrm{AccP} \ldots]\right.\right.$... Gen $]$ Pol/Rus.

Russian allows the variants (26a-b), while Polish allows only for (26b). In Polish whenever the probe $\mathrm{T}$ cannot find a nominal goal that is marked for Nom its $\varphi$-features default to $3_{\text {SG.NEUT. }}$ Though the probe $\mathrm{T}$ has a choice of two close $(\mathrm{r})$ goals neither can value its $\varphi$-features and T defaults. In Russian two subject/verb concord possibilities are available but they are not fully equivalent. We assume that the Agree operation in which the $\varphi$-features of T are fully valued is more economical (and generally preferable) to the option in which they default. Say that defaulting involves an extra derivational step and incurs extra burden on the derivation (cf. Preminger 2009). Thus whenever the QP has the structure in (26a), T shows full agreement in Russian. In the cases of default agreement the Russian QP shares its structure with its Polish equivalent. As for the puzzling agreement with the head of the Participle Phrase or predicative adjective in Polish, the relevant configuration is the same. The probe needs to agree for case with either goal that bears this feature; as it happens two candidates are locked in this configuration:

$$
\text { Part }\left[{ } _ { \text { GenP } } \left[{ }_{\text {AccP }}\right.\right. \text { te pięć dziewczyn...] Gen ] }
$$

Unlike T, Part has an incomplete $\varphi$-probe, which misses the [ person] feature and functions as a passive recipient of the features provided by its nominal goal and probe T. A default T makes no claims on the features of Part, whereas both GenP and AccP are close to Part on the strength of (22), providing it with a free option. ${ }^{21}$ Therefore Part

21 The variation within the case marking of a demonstrative (i.e., accusative or genitive, qualifying the numeral only or the entire QP, see fn.6 for relevant examples) as well as it scope does not correlate with the case on the participle. What matters here is the timing of adjunction of a de- 
can become involved in Agree and valuation either with AccP or GenP. As a result, the agreement for $\varphi$-features is optional. ${ }^{22}$ Significantly, the account based on articulated KP and case-driven movement does not overgenerate in that it also predicts that optional agreement does not apply in cases of the concord holding between a verb (selected by a $\varphi$-complete $\mathrm{T}$ ) and a nominative subject containing a specifier (or complement) in genitive. In such complex nominal structures the genitive is a case of an extended nominal projection separate from the projection of the nominal head. On the basis of the assumption that KP is projected on top of each NP, we predict the following (simplified) structure:

(28) a) T ... [jego [książka] $]$

b) $\mathrm{T}\left[\left[_{\mathrm{NomP}}\left[{ }_{\mathrm{NP}}\left[{ }_{\text {GenP }}\right.\right.\right.\right.$ jego $]\left[\left[_{\mathrm{N}}\right.\right.$, książka... $\left.\left.\left.]\right]\right]\right]$ is borrowed $_{\mathrm{NOM}}$ 'his book is borrowed'
a) księga gości została zgubiona/*zgubionych book $_{\mathrm{NOM}}$ guests $_{G E N}$ was lost $_{\mathrm{NOM} / * \mathrm{GEN}}$
b) $\left[_{\mathrm{NomP}}\left[{ }_{\mathrm{NP}} \operatorname{księga~[{}_{\text {GenP}}[\mathrm {NP}}\right.\right.$ gości] $\left.\left.]\right]\right]$
'The guestbook has been lost lost.'

Irrespective of the exact internal structure of (28-29) the possessive GenP is inactive for $\varphi$-feature Agree, as its derivational cycle (phase) came to its end when $\mathrm{N}$ accessed the KP, i.e., we deal with separate nominal projections with their separate KPs, one properly embedded in the other. This is very different from the hybrid and idiosyncratic structure in (22), where a single extended projection of the noun had to accommodate two case-greedy nominal elements, with multiple movements within KP and predictable consequences for the optionality of case-driven Agree.

\section{CONCLUSION}

The nanosyntactic approach shows via structural means the specificity of the GoQ construction: a single nominal constituent headed by $\mathrm{N}$ and insulated within a single functional sequence (FP, KP) begins its derivational life. In order to cope with a situation when the functional head $\mathrm{Q}$ gets to bear a nominal quality and requires its own case independent of $\mathrm{N}$, a sequence of case driven movements within a single $\mathrm{KP}$ is posited. First QP is raised to [spec, Acc] to satisfy an external probe (T/v) and next, NP

monstrative to QP, i.e., whether it moves from within NP after genitive marking of the NP, or it receives accusative once it adjoins to QP. A detailed derivation of structures with demonstratives is discussed in Witkoś and Dziubała-Szrejbrowska (2016).

22 In order to explain these agreement properties Przepiórkowski and Patejuk (2012) propose, within the formalism of LFG, that the numeral subject should have a hybrid structure similar to coordination and point out that Polish allows for the initial conjunct agreement and the final conjunct agreement (much less frequently). Our account avoids the question of the robust difference in frequency between the optional agreement forms of the participle/adjective agreeing with QP and distant conjunct agreement in Polish. 
(pied-piping the QP above it) is raised to [spec, Gen]. The double satisfaction of the case requirements produces a structure of a distinct potential for case feature checking of the participle and predicative adjective.

\section{References}

BABBY, Leonard (1987) "Case, prequantifiers, and discontinuous agreement in Russian." Natural Language and Linguistic Theory 5, 91-138.

BAILYN, John F. (2004) “The case of Q." In: Olga Arnaudova (ed.), 1-36.

BLAKE, Barry (1994) Case. Cambridge University Press: Cambridge.

BOŠKOVIĆ, Željko (2005) "On the locality of left branch extraction and the structure of NP." Studia Linguistica 59, 1-45

BOŠKOVIĆ, Željko (2006) Case and agreement with genitive of quantification in Russian. In: Cedric Boeckx (ed.), 99-120.

BOŠKOVIĆ, Željko (2013) More on the edge of the edge. In: Cassandra Chapman/ Olena Kit/Ivona Kucerova (eds), 44-66.

CAHA, Pavel (2009) Nanosyntax of case. PhD Dissertation. University of Tromso.

CAHA, Pavel (2010) The parameters of case marking and spell out driven movement. http://ling.auf.net/lingbuzz/001026.

CAHA, Pavel (2012) Czech numerals. Paper presented at Cartography - Where do we go from here?, Geneva, June 7-9, 2012.

CAHA,Pavel(2013)Czech numerals and no bundling.http://ling.auf.net/lingbuzz/001723.

CINQUE, Guglielmo (2005) "Deriving Greenberg's Universal 20 and its exceptions." Linguistic Inquiry 36, 315-332.

CHOMSKY, Noam (1995) The Minimalist Program. Cambridge, MA: the MIT Press.

CHOMSKY, Noam (2000) Minimalist inquiries. In: Robert Freidin, Carlos P. Otero, and Maria Luisa Zubizarreta (eds) Foundational issues in linguistic theory. Cambridge, MA: MIT Press, 89-156.

CHOMSKY, Noam (2001) "Derivation by phase." In: Michael Kenstowicz (ed.), Ken Hale. A Life in Language. Cambridge, Mass.: The MIT Press, 1-52.

CHOMSKY, Noam (2008) On Phases. In: Robert Freidin/Carlos P. Otero/Maria Luisa Zubizarreta (eds), 133-166.

CORBETT, Greville G. (1978a) "Numerous squishes and squishy numerals in Slavonic." International Review of Slavic Linguistics 3, 43-73.

CORBETT, Greville G. (1978b) "Universals in the syntax of cardinal numerals." Lingua $46,355-368$.

GREENBERG, Joseph. H. (1978) Generalizations about numeral systems. In: Joseph H. Greenberg (ed.), Universals of Human Language. Vol 3. Stanford: Stanford University Press, 249-295.

FRANKS, Steven (1994) "Parametric properties of numeral phrases in Slavic." Natural Language and Linguistic Theory 12, 597-674.

FRANKS, Steven (1995) Parameters of Slavic morphosyntax. New York: Oxford University Press. 
FRANKS, Steven (2002) "A Jakobsonian feature based analysis of the Slavic Numeric Quantifier Genitive." Journal of Slavic Linguistics 10, 141-181.

MIECHOWICZ-MATHIASEN, Katarzyna (2014) Numeralization of numeral nouns in Polish. In: Ludmila Veselovská/Markéta Janebová (eds), 48-68.

PERELTSVAIG, Asya (2006) "Small nominals." Natural Language and Linguistic Theory 24, 433-500.

PESETSKY, David (1982) Paths and Categories. PhD Dissertation. Massachusetts Institute of Technology.

PESETSKY, David (2013) Russian case morphology and the syntactic categories. Cambridge: The MIT Press.

PESETSKY, David/Esther TORREGO (2001) T-to-C movement: Causes and consequences. In: Michael Kenstowicz (ed.), 355-426.

PREMINGER, Omer (2009) Failure to Agree is not a failure: $\varphi$-Agreement with postverbal subjects in Hebrew. Manuscript. MIT/ Harvard.

PRZEPIÓRKOWSKI, Adam. (1999) Case assignment and the complement-adjunct dichotomy: A non-configurational constraint-based approach. PhD Dissertation. Universität Tübingen.

PRZEPIÓRKOWSKI, Adam (2004) "O wartości przypadka podmiotów liczebnikowych.” Bulletin De La Société Polonaise De Linguistique, fasc. LX, 133-143.

PRZEPIÓRKOWSKI Adam/Agnieszka PATEJUK (2012) The puzzle of case agreement between numeral phrases and predicative adjectives in Polish. In: Miriam Butt/Tracy H. King (eds), 490-502.

RIZZI, Luigi (1990) Relativized Minimality. Cambridge: The MIT Press.

RICHARDS (1998) “The Principle of Minimal Compliance.” Linguistic Inquiry 29/4, 599-629.

RICHARDS, Norvin (2007) "Lardil 'Case Stacking' and the structural/inherent case distinction". Unpublished manuscript. Massachusetts Institute of Technology.

RUTKOWSKI, Paweł (2002) "The syntax of quantifier phrases and the inherent vs. structural case distinction." Linguistic Research 7/1, 43-74.

RUTKOWSKI, Paweł (2007) Hipoteza frazy przedimkowej jako narzędzie opisu sktadniowego polskich grup imiennych. PhD Dissertation. Uniwersytet Warszawski.

STARKE, Michal (2009) "Nanosyntax: A short primer to a new approach to language." Nordlyd 36/1, 1-6.

SVENONIUS, Peter (2004) On the edge. In: David Adger/Cécile de Cat/GeorgeTsoulas (eds), 261-287.

TARALDSEN, Tarald (2009) "Lexicalizing number and gender in Lunigiana." Nordlyd 36, 113-127.

WILLIM, Ewa (2000) “On the grammar of Polish nominals.” In: Roger Martin/David Michaels/Juan Uriagereka (eds), 319-346.

WITKOŚ, Jacek/Dominika DZIUBAŁA-SZREJBROWSKA (2015) "A note on the Genitive of Quantification in Polish and derivational phrases." Poznań Studies in Contemporary Linguistics 51(3), 433-462. 
WITKOŚ, Jacek/Dominika DZIUBAŁA-SZREJBROWSKA (2016) "Numeral phrases as subjects and agreement with participles and predicative adjectives." Journal of Slavic Linguistics 24(1), 225-260.

\section{Summary \\ SOME ASPECTS OF AGREEMENT WITH NUMERAL PHRASES IN POLISH}

The aim of this article is to briefly analyze the agreement patterns in Polish constructions with quantified subjects and adjectival predicates/participles, and propose an account built on the nanosyntactic ideas regarding the nature of case, i.e., split Kase Phrase (Caha 2009, 2010). In the analysis we address the troublesome issues regarding the Genitive of Quantification, i.e., the source of Genitive on the nominal complement in structural contexts, and the optionality in agreement in case between the adjectival predicate/participle and the numeral $(\geq 5)$, or the noun of the quantified subject. The essential part of our proposal is based on the articulated Kase Phrase in the functional sequence of the extended nominal projection and its role in the syntactic derivation of case in the spirit of nanosyntactic approach.

Keywords: adjectival and participial agreement, Genitive of Quantification, split KP, quantified subjects

\section{Povzetek}

\section{NEKATERI VIDIKI UJEMANJA S ŠTEVNIŠKIMI ZVEZAMI V POLJŠČINI}

Namen članka je kratko analizirati vzorce ujemanja v zgradbah s kvantificiranim osebkom in pridevniškim predikatom/deležnikom v poljščini ter predlagati razlago, ki temelji na nanoskladenjskem pristopu $\mathrm{k}$ naravi sklona, tj. na podlagi deljene sklonske zveze (Caha 2009, 2010). V analizi se ukvarjamo s problematičnimi vidiki kvantifikacijskega rodilnika, tj. z izvorom rodilnika na samostalniškem dopolnilu v strukturalnih kontekstih ter s poljubnostjo ujemanja $\mathrm{v}$ sklonu med pridevniškim predikatom/ deležnikom in števnikom ( $\geq 5)$ ali samostalnikom kvantificiranega osebka. Bistveni del naše teorije temelji na artikulirani sklonski zvezi znotraj funkcijskega niza razširjene samostalniške projekcije in njeni vlogi pri skladenjski derivaciji sklona v duhu nanoskladenjskega pristopa.

Ključne besede: pridevniško in deležniško ujemanje, kvantifikacijski rodilnik, deljena sklonska zveza, kvantificirani osebek 